\title{
Why Small Mining?
}

14 other countries of the world produced as much copper as the small miners of Chile ( $\mathrm{H}$. Marinovic Molinos, in Meyer and Carman, 1980).

R. Nötstaller (Austroplan, Vienna, 1986, unpublished) has reviewed classification units adopted or proposed by many different authors (see also UN, 1972). This suggests that an upper annual limit of about 100,000 tons of run-of-mine output should be accepted as the size definition of small-scale mining when making global generalizations. In general only two

With the major mining industry in great difficulty worldwide, many organizations and investors are now turning to the small-scale mining and mineral industry sector, an employer of large numbers of people in many developing countries. This article reviews the characteristics of small mining and suggests some ways to strengthen its contribution to economic development, especially in the Third World. The focus on this sector is timely in view of the recent proposal to set up "Small Mining International," described elsewhere in this issue. (Ed.)

\section{Background}

With the United Nations Institute for Training and Research (UNITAR) as the prime mover, the first international conference on small-scale mining was held in Jurica, Mexico, in late 1978 (Meyer and Carman, 1980). It was an important meeting hailed by the participants as an outstanding success. To the degree that the meeting heightened consciousness of the small-scale mining industry, its problems and potential, that appraisal was warranted. But almost a decade later, it is evident that little that is concrete has materialized, despite many other expressions of support for small operations (e.g. Anon, 1983; Carman and Varon, 1979; Carman, 1985; Dahlberg, 1984; Neilson, 1982; Yuill, 1985).

\section{DEFINING SMALL MINING IN INDIA}

Perhaps because its small mining sector is so large, there is special interest in India in the careful definition of a small mine. One current proposal, being championed by MGMI, sets upper limits for the annual production of different minerals in "raw unprocessed form, as measured at the entrance to the mine" and "subject to the maximum investment in plants, machinery and equipment up to a limit of Rs 6 millions [about $\$ 460,000$ US] without any mechanized beneficiation and up to a limit of Rs 10 millions [about $\$ 750,000$ US] with such a unit." For example, the annual upper limit for a small mine producing emeralds is 2,000 carats; asbestos 1,000 tones; gold 5,000 tonnes; copper 25,000 tonnes; and limestone and iron ore 100,000 tonnes.

\section{Definition of Small-Seale Mining}

At the Jurica meeting no agreed definition of the small mining industry in quantitative terms emerged. In fact, there was no attempt to do so because, in effect, two languages were used with little mutual comprehension. To those from the industrial nations, a base-metal operation producing less than about 700 tons daily is considered to be small. At the other end of the scale, in developing countries the average small metalliferous mine might produce 5-10 tons daily and that often on a sporadic basis. For example, in the late 1970s in Chile the average shipper of copper ore to the plants of the Empresa Nacional de Mineria produced about 10 tons per day of ore (Fig. 1), yet at that time only parameters - volume and value - are involved, but individual nations will often use other measuring rods, such as capital investment or degree of mechanization (see Fig. 3 and accompanying box).

\section{Characteristics of Small Mining}

The typical mine operating on a small-seale in the Third World is a producer, of ten sporadically, of limited amounts of minerals from deposits with few known ore reserves and of a character not readily amenable to mass mining (Fig. 2). Output is won without much use of mechanical energy and by exploitation of labour under leadership that commonly lacks technical, managerial and entrepreneurial skills (Fig. 4). Small-scale mining can lead to serious wastage of non-renewable resources by high-grading, which

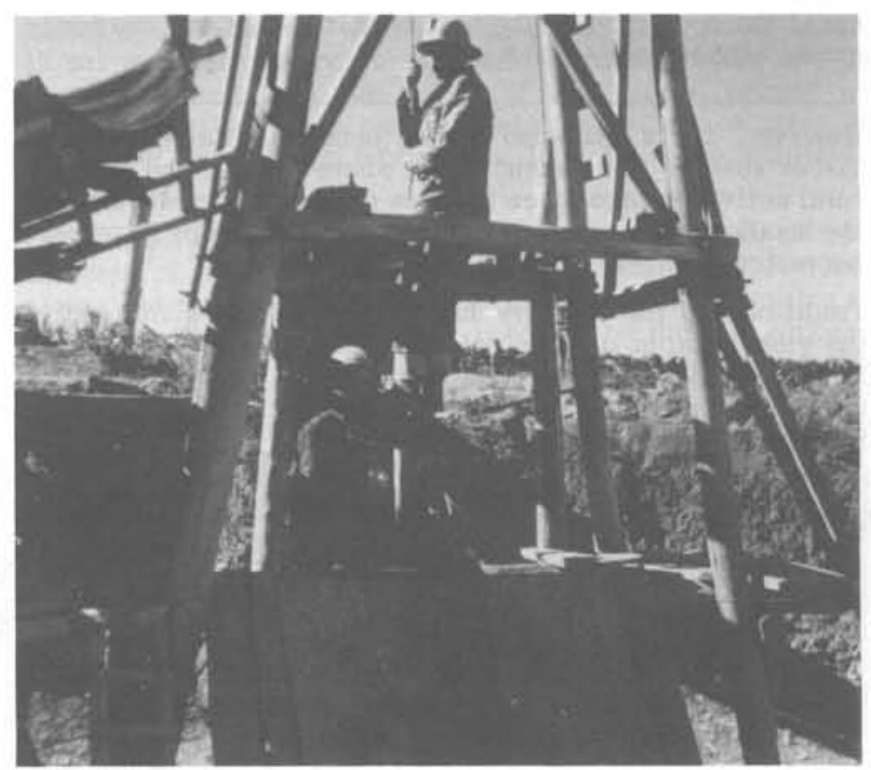

Figure 1: Descending a $200 \mathrm{~m}$ shaft the hard way. Small copper mine, Chile.

leaves behind a lot of uneconomic mineralization that could have been recovered if mined on a larger scale. Paradoxieally small mining can also enrich nations and the world as a whole by playing the useful role of scavenger. Per unit of output, it is a prolific employer of labour (e.g. cover photo), and though the terms may be harsh the alternative is frequently something close to starvation.

Typically, the small mine owner pays little attention to laws and regulations. Some years ago, for example, in the copper mines of Chile it cost one-fifth the prevailing rates at the major mines to employ a worker in a small operation. It could hardly be otherwise. With very little, if any, mechanization, output per man-shift is very low indeed (Fig. 5). 


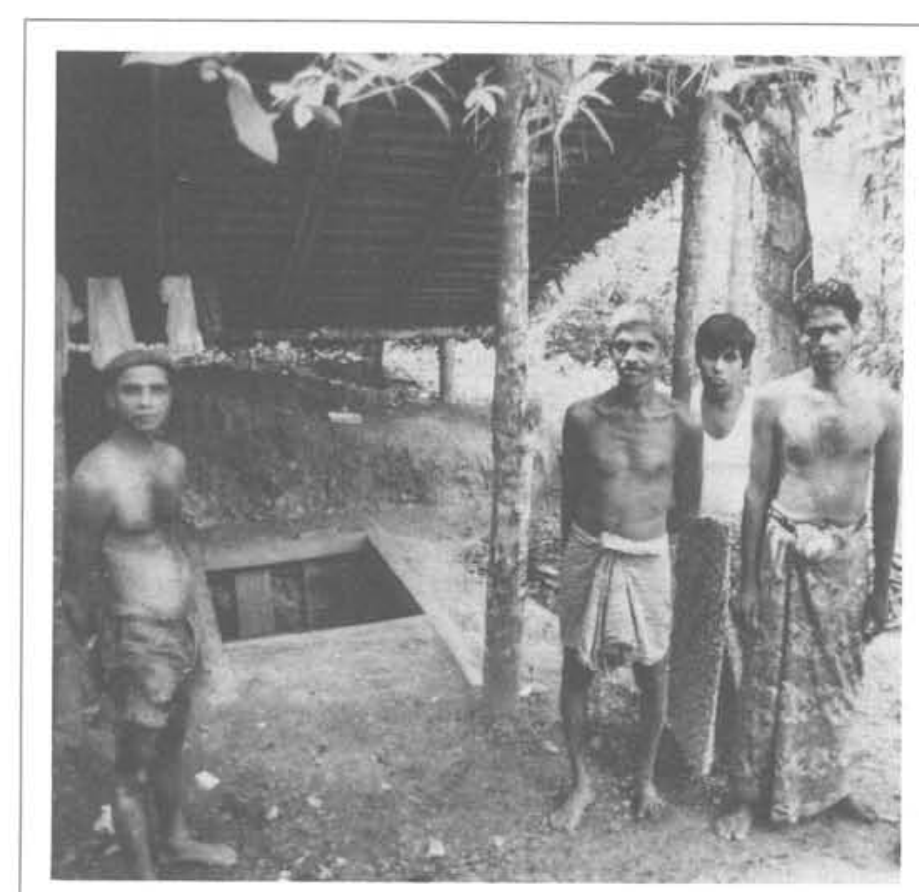

Figure 2: Entrance to a very small vermiculite mine, Rattota, Sri Lanka. Shaft about $10 \mathrm{~m}$ deep. Reserves 200 tonnes, vein $0.6 \mathrm{~m}$ wide. Operated by a rural co-operative. Output sold to a state corporation. (Photo by A.R. Berger)

However, there are also social benefits. Particularly in places such as Bolivia and Peru where mining and agricultural activities take place in close proximity, employment in the small mines may rise dramatically after crops have been harvested.

Traditionally, the industry has been credited with $10 \%$ of the global output of non-fuel minerals. That is a suspicious figure, and a recent analysis (Table 1) indicates that small mining accounts for at least $16 \%$ of total world mineral production (Carman, 1985).

\section{The Decline of World Mining}

Any discussion of mining today takes place against a background of crisis in the world mineral industry. There is an understandable tendency to view the difficulties of the past few years as a reflection of the "boom or bust" nature of the free enterprise system. The extraordinarily strong growth of minerals usage since World War II has indeed been interrupted by relatively short term and mild recessions. Thus, the economic turmoil of the past decade has been regarded by many as simply another manifestation of the cyclical pattern in mineral affairs. It is anything but. Rather it is part of a trend of long duration (Fig. 6).

The life history of the demand for most, if not all, minerals closely mirrors that of Man: youth blessed by

Figure 3: Hand-cobbing manganese laterite at a semi-mechanized small mine employing 50 men and 50 women, Noamuni district, Bihar, India. (Photo by C. Pride) energy turning into staid middle age and then on the decline. For example, Larson and others (1986) show that in the U.S.A. production of steel, the basic metallic indicator, has been declining steadily since 1919 in terms of kilograms per $\$ 1000$ of GNP (in 1983 dollars), being appreciably less in 1980 than it was in 1890 .

They suggest the end of an age. "In recent years there appears to have been a fundamental change in this pattern of growth. In North America, Western Europe and Japan economic expansion continues but the demand for many basic materials has levelled off. It appears that the industrial countries have reached a turning point. They are now leaving the era of materials, which spanned the two centuries following the advent of the Industrial Revolution and are moving into a new era in which the level of materials used will no longer be an important indicator of economic progress" (Larson et al., 1986). One could debate the concluding words, but the thesis is seen to be well founded when the following are considered.

First, there is the ever-increasing economy of use. As an extreme example, early in the 19th Century the ratio of weight to power in a steam locomotive was approximately $1000 \mathrm{~kg}$ per horsepower. Today it is about $14 \mathrm{~kg}$. Second, plastic and ceramic materials are continuously replacing metals. It is difficult to recall a significant reversal of this process. And how does one factor into forecasts such things as the imminent entry into commerce of superconductors. Third, there is the Third World debt. This cannot be repaid, for the developing nations are hard put even to feed their exploding populations. Yet Western industry can only stay above break-even point by exporting to developing nations production surplus to local consumption, voracious though that may be. This contradiction is explosive, but nowhere is there much sign of the statesmanship required for a solution.

Finally, there are the environmental problems that have been swept under the rug for a long time. Many years ago, the price to be paid was forecast by D.B. Brooks (1973) "Contrary to conservationist tradition, I see most nonrenewable resources as all but continually available over time, whereas the supposedly renewable resources such as air and water are in jeopardy of depletion." It is now evident that time is running short. 


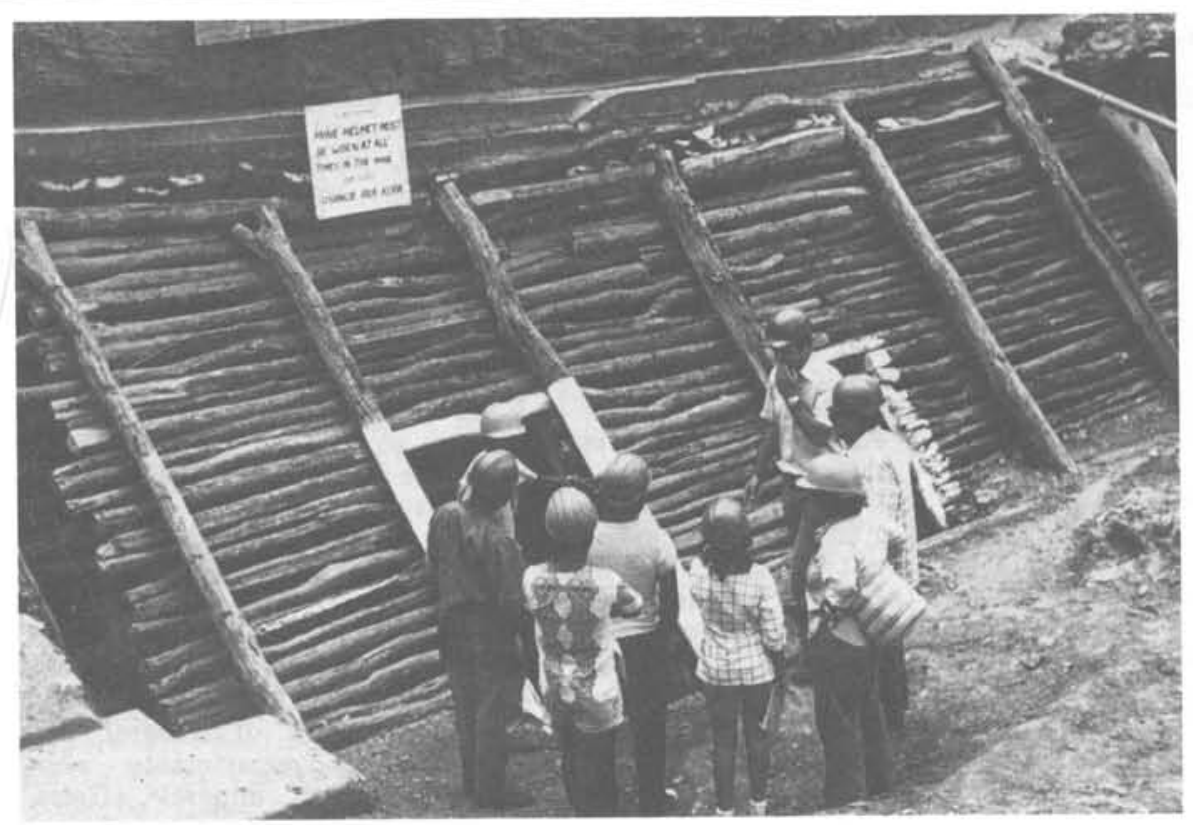

be minimal, and the company will probably not be sufficiently visible to excite political interest. Such attention tends to manifest itself in strong action by governments, especially when ownership is foreign and the company looms large in the economic picture of the country concerned.

In the past, many major mining houses have tended to dismiss small operations as not worth the administrative headaches. This objection can perhaps be met by real decentralization. And the long view may see the small operation as an inexpensive way to establish a position in a country, to demonstrate enlightened policies and to maintain an observation post at no cost from which other opportunities may be revealed from time to time. The process, if intelligently planned, should produce an interesting return on investment.

\section{The Need for Information}

To develop and strengthen the small mining sector requires particularly

Figure 4: Entrance to the Laulenyi Tsavorite Mine, Taita Hills, Kenya. A rare example of excellent technical skill and management in a small operation. (Photo by D. Briggs)

For the major mineral sources for metals such as $\mathrm{Fe}, \mathrm{Al}, \mathrm{Cu}$, $\mathrm{Pb}, \mathrm{Zn}, \mathrm{Ni}$ and $\mathrm{Mn}$, proved and in some instances developed reserves are ample to carry the world well into the 21 st Century. This excess of riches having led to real metal prices as low as those of the Great Depression, the major mining companies have become rather timid after being bloodied by events of recent years. Using copper as an example, in the $1970 \mathrm{~s}$ the following great and comparatively rich ore bodies were considered well on their way to production - Cerro Colorado and Petaquilla in Panama, Toromocho, Michiquillay and Quellovaco in Peru, LoS Pelambres and Andocollo in Chile, Sar Chesmeh in Iran and Saindak in Pakistan. Today they are just as far from producing blister as they were ten years ago, despite expeditures totalling billions of dollars.

\section{A Focus on Small Mining}

This is a dark picture. Yet paradoxically it could portend a considerably brighter future for small mining. If only to remain competitive, the major mining houses must maintain in-house mine-seeking and developing capacity. And always there will be the entrepreneurs, who historically have been the most important force in the finding of new mines (Fig. 7). To these companies and people, small- to mediumscale mining has become quite attractive.

Grass-roots exploration should not be required, so there may be little risk involved. Instead, effort tends to be focussed upon already operating properties within established mining districts. Access to the third dimension makes for comparatively easy evaluation and in many cases permits extrapolation to the larger picture. Thus, the small mine may prove to be the springboard to a major operation. Indeed, the history of mining is in a very real sense the history of small mines.

With a large mine in a new environment, the time span between the first stages of exploration and production will tend to be ten years or more. With a small operation starting from an already revealed deposit, no more than two to three years should be required. Capital investment will good documentation. Small mine operations seldom have access to technical information such as that dealing with mineral exploration, mining and processing practice and equipment. International trade in minerals is a complicated business, particularly with non-metallies. The small miner is not generally privy to opportunities and pitfalls and is thus more-or-less at the mercy of ore buyers, private or public. Anything that can increase awareness of what is happening around the world may lead to more equitable negotiations.

of course, the small-scale mine does not attract the interest of the technical journals with worldwide circulation. The attractiveness of news on mining opportunities in the Third World and elsewhere tends to be directly proportional to scale. Thus, a great deal of valuable information is never brought to light. Governments may lack the perspective to see the larger picture and be unable, therefore, to

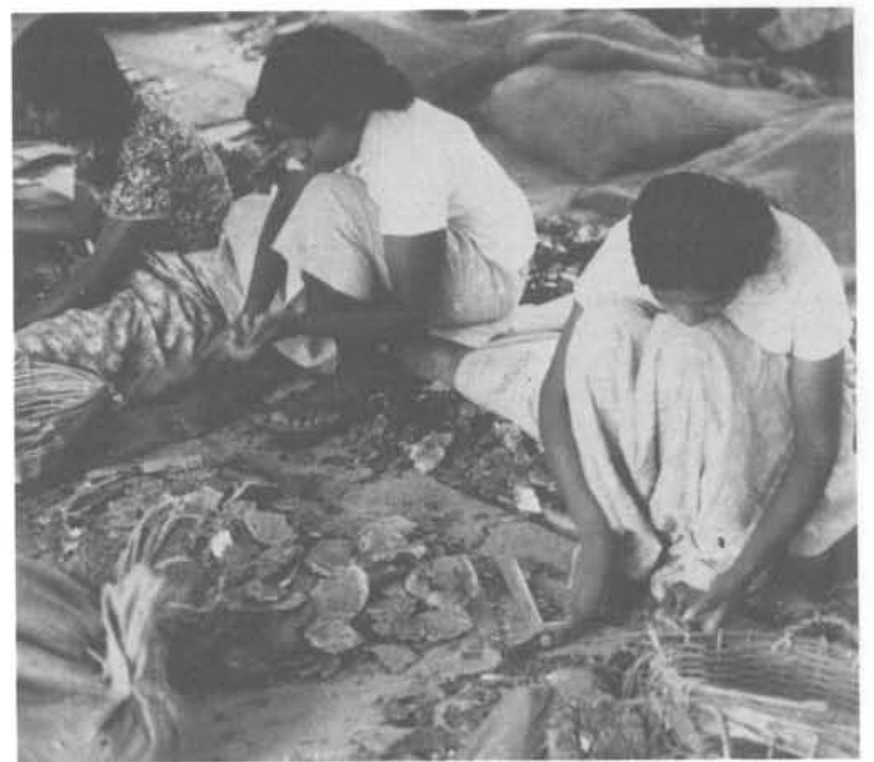

Figure 5: Cobbing mica by hand. State Mining Corporation, Pallekelle, Sri Lanka. (Photo by A.R. Berger) 
*TABLE 1: Estimated Value of Small Mining Sector in the Production of Non-Fuel Minerals in 1982

\begin{tabular}{|c|c|c|c|c|c|}
\hline Mineral & $\begin{array}{l}\text { Gross Value } \\
\text { of Output } \\
\text { ( } \$ \text { Millions) }\end{array}$ & $\begin{array}{l}\text { Share of Sma11- } \\
\text { scale Mining } \\
\text { (\%) }\end{array}$ & $\begin{array}{l}\text { Gross value of } \\
\text { Small-scale Mining } \\
\text { ( } \$ \text { Millions) }\end{array}$ & $\begin{array}{l}\text { Price } \\
\text { (US\$) }\end{array}$ & $\begin{array}{l}\text { Quantity } \\
\text { (Thousands) }\end{array}$ \\
\hline Antimony & 126 & 45 & 57 & $1.07 / 1 \mathrm{~b}$ & $59 \mathrm{st}$ \\
\hline Asbestos & 1,444 & 10 & 144 & $335 / \mathrm{mt}$ & $4,311 \mathrm{mt}$ \\
\hline Barite & 300 & 60 & 180 & $38 / s t$ & 7,887 st \\
\hline Bauxite & 3,008 & Negligible & & $40.42 / \mathrm{mt}$ & $74,441 \mathrm{mt}$ \\
\hline Beryllium & 38 & 100 & 38 & $6.30 / 1 \mathrm{~b}$ & $3 \mathrm{st}$ \\
\hline Bismuth & 15 & Negligible & & $1.87 / 1 \mathrm{~b}$ & 4 st \\
\hline Boron & 778 & Negl igible & & $311 /$ st & $2,503 \mathrm{st}$ \\
\hline Bromine & 620 & Negligible & & $0.75 / 1 b$ & 413 st \\
\hline Cadmium & 39 & Negligible & & $1.11 / 1 \mathrm{~b}$ & $16 \mathrm{mt}$ \\
\hline Chromite & 633 & 50 & 316 & $58 / \mathrm{st}$ & 10,907 st \\
\hline Clays & 2,592 & 75 & 1,944 & varies & 149,803 st \\
\hline Cobalt & 675 & 10 & 68 & $12.50 / \mathrm{st}$ & $27 \mathrm{st}$ \\
\hline Columbium & 97 & Negligible & & $3.04 / 1 \mathrm{~b}$ & $16 \mathrm{st}$ \\
\hline Copper & 12,812 & 8 & 1,025 & $0.73 / 1 b$ & 7,963 st \\
\hline Feldspar & 124 & 80 & 99 & $33 / 5 t$ & $3,745 \mathrm{st}$ \\
\hline Fluorspar & 745 & 90 & 670 & $149 / \mathrm{st}$ & $5,003 \mathrm{st}$ \\
\hline Gold & 16,060 & 10 & 1,606 & $376 /$ tr.oz & $42,713 \operatorname{tr}$ oz \\
\hline Graphite & 221 & 90 & 199 & $364 / \mathrm{st}$ & 607 st \\
\hline Gypsum & 682 & 70 & 477 & $8.46 / \mathrm{st}$ & $80,676 \mathrm{st}$ \\
\hline Iron ore & 32,638 & 12 & 3,917 & $41.72 / 1 t$ & $782,3021 \mathrm{t}$ \\
\hline Lead & 1,977 & 11 & 217 & $0.26 / 1 \mathrm{~b}$ & $3,450 \mathrm{mt}$ \\
\hline Magnesium & 731 & Negligible & & $1.34 / 1 \mathrm{~b}$ & 273 st \\
\hline Manganese & 1,634 & 18 & 294 & $66 / s t$ & $24,754 \mathrm{st}$ \\
\hline Mercury & 77 & 90 & 69 & $377 / f 1$ & $204 \mathrm{st}$ \\
\hline Molybdenum & 158 & Negligible & & $7.90 / 1 b$ & $100 \mathrm{st}$ \\
\hline Nickel & 4,512 & Negligible & & $3.20 / 1 \mathrm{~b}$ & $705 \mathrm{st}$ \\
\hline Phosphate rock & 3,788 & 10 & 379 & $31 / \mathrm{mt}$ & $122,202 \mathrm{mt}$ \\
\hline Platinum group & 1,801 & Negl igible & & $280 /$ tr.oz & 6,431 tr.oz \\
\hline Potash & 3,830 & Negligible & & $146 / \mathrm{mt}$ & $26,230 \mathrm{mt}$ \\
\hline Pumice & 114 & 90 & 103 & $9 / \mathrm{st}$ & $12,702 \mathrm{st}$ \\
\hline Salt & 2,703 & 20 & 541 & $14.53 / \mathrm{st}$ & $186,000 \mathrm{st}$ \\
\hline Sand and gravel & 10,103 & 30 & 3,031 & $3.23 / 5 t$ & $3,128,000 \mathrm{st}$ \\
\hline Silver & 2,962 & 10 & 296 & $7.95 /$ tr.oz & 372,528 tr. 02 \\
\hline Stone & 14,957 & 30 & 4,487 & $3.78 / \mathrm{st}$ & $3,957,000 \mathrm{st}$ \\
\hline Sulphur & 5,471 & Negligible & & $108 / \mathrm{st}$ & $50,660 \mathrm{st}$ \\
\hline Talc and pyrophyllit & te 182 & 90 & 164 & $24 / 5 t$ & $7,595 \mathrm{st}$ \\
\hline $\operatorname{Tin}$ & 3,118 & 15 & 468 & $5.87 / 1 \mathrm{~b}$ & $241 \mathrm{mt}$ \\
\hline Titanium & 413 & Negligible & & $84 / \mathrm{st}$ & 4,922 st \\
\hline Tungsten & 272 & 80 & 218 & $5.67 / 1 \mathrm{~b}$ & $24 \mathrm{st}$ \\
\hline Vermiculite & 51 & 90 & 46 & $90 / s t$ & $564 \mathrm{st}$ \\
\hline $\begin{array}{l}\text { Zinc } \\
\text { Totals }\end{array}$ & $\begin{array}{r}5,064 \\
\$ 137,565 \\
\end{array}$ & 11 & $21, \frac{557}{610}$ & $0.38 / 1 \mathrm{~b}$ & $6,047 \mathrm{mt}$ \\
\hline
\end{tabular}

* After Carman, 1985. especially developing ones, this data will only occasionally be found neatly stored and indexed in central repositories. Instead, in a typical country it will be scattered through the files of various ministries and agencies, development and commercial banks, company records, universities and the private libraries of the professors who teach in them.

The experience of the United Nations with a project in the Province of Mendoza, Argentina some years ago may be quoted as an example of what might be done. The area seemed to be almost "terra incognita," when judged on the basis of what could be found in the archives of federal and provincial departments concerned with mineral affairs. Thus, prior to a photogeological survey, a relatively minor amount of money was paid for a search of the literature by a group of local geologists for a total of about 36 personmonths. The result was a standard four-drawer filing cabinet being crammed full with reports, plus a list of approximately 2300 mineral showings, about $10 \%$ of which were considered worthy of follow-up. This was in an agricultural province with virtually no mineral industry or history of mining.

At the other extreme, there are reports mouldering away at the United Nations' headquarters in New York that chronicle about $\$ 400$ million in mineral exploration costs. The salient features of these documents cannot even be recovered by punch card. Copies are deemed to exist in the countries concerned, but the question of accessibility arises again. make sound data readily available on a wide enough basis to ensure a truly competitive response. Prospective investors both local and foreign have missed many opportunities or taken on losing propositions by relying on opinions of those ill-prepared to make sound analyses of the total environment concerned.

Most Third World mining associations are not very functional, if only because of being ill-informed and perenially under-financed. Accordingly, the effective voice for miners must have access to reliable intelligence on circumstances at home and abroad in regard to supply and demand, commercial trends affecting trade in minerals, mine financing, trade barriers, technical advances, and a host of other factors that determine the state of health of all who produce commodities for export.

Much of this information already exists, but there is a staggering task in collecting, collating and computerizing it. The amounts are enormous, but in many countries,
Small mining operations as a whole are chronically underfinanced. Accordingly, paths are worn down in the direction of banks, private and public. To survive such institutions have to employ the best technical people to evaluate the feasibility and supervise the application of loans. It is reasonable to expect, therefore, that any country seeking funds for development would facilitate access to such data.

What is needed then is an information source with emphasis on mineral deposits and districts, particularly where the number of workings permits the recognition of controls that could lead to delineation of important deposits. The background data, which can be all-important, must also be developed to provide a coherent whole: kinds and quality of infrastructure; the characteristics and record of the labour force; labour law; the fiscal codes, rates and guarantees; and mining law covering acquisition and retention of mineral rights and operating regulations. Up-dating such information would be essential and continuous function. 


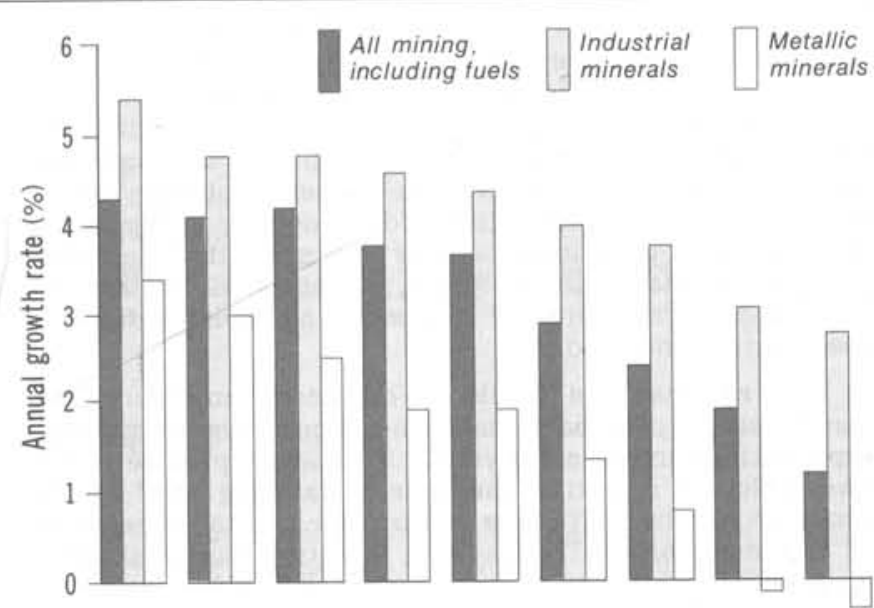

$63-75 \quad 64-76 \quad 65-77 \quad 66-78 \quad 67-79 \quad 68-80 \quad 69-81 \quad 70-82 \quad 71-83$ GSC

Figure 6: Decline of value of world mining output in terms of growth rates, 1963-1983. Source: Yearbook of Industrial Statistics, United Nations, New York.

\section{Towards an Information Centre for Small Mining}

Two interesting and successful precedents involving UNITAR are worth quoting here. Following a meeting in 1979 dealing with heavy crude and tar sands, a committee was convened including, among others, representatives of the Venezuelan petroleum authority, the U.S. Department of Energy, the Oil Sands Research Authority of Alberta and Petro-Canada. About two years of preparation and approximately $\$ 1,000,000$ in seed money were required to set up the Information Centre on Heavy Crude and Tar Sands in New York, which is managed by UNITAR/UNDP. Within less than two years the operation became self-sustaining, with an annual budget of about $\$ 400,000$ which comes from corporate and public clients. The Centre produces annually an authoritative world survey and every three months a newsletter. It maintains a watching brief on legislation and regulations affecting the petroleum industry.

The genesis of the Centre produced a precedent of fundamental importance for the development of any similar organizations. Initially, the legal office held that the United Nations as a body of sovereign governments could not have an agency strongly linked to private companies. This opinion was overruled by the Secretary-General.

A few years later, the Information Centre for Small Energy Resources came into being with headquarters in Rome. To set this up the Italian Government provided $\$ 700,000$ over two years and the Belgian Government an additional $\$ 70,000$. This Centre, however, cannot depend largely upon a relatively few but enormously wealthy concerns such as those of the international petroleum world. Instead, support is sought from a wide range of subscribers paying a modest fee on the order of $\$ 3,000$ annually.

The small-seale mining industry more than justifies the exposure that an equivalent centre would provide. There are undoubtedly several governments that could be interested in hosting an information centre for small mining, given a sound proposition and assurances that the services to be offered would be of sufficient value to ensure early achievement of financial independence.

\section{Conclusion}

There is no question that small-scale mining contributes notably to global output of minerals. Of even greater importance, it has traditionally been the rootstock from which most great mines come. For example, almost all

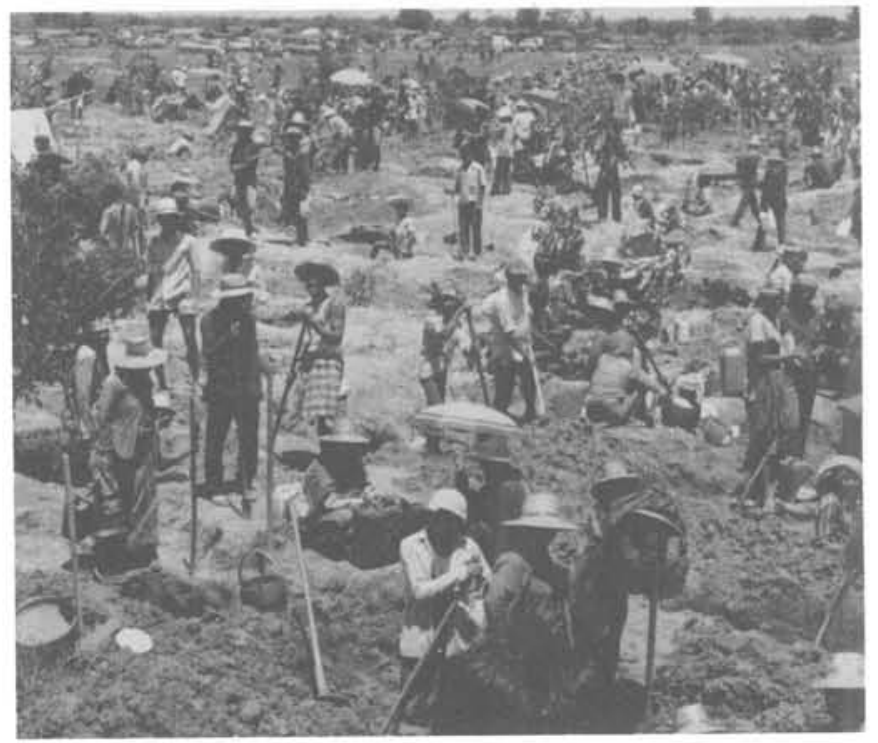

Figure 7: Digging for gold - Kabinburi, Thailand. A steady income for parking lot owners and sellers of cool drinks, and a chance of a fortune for individual "miners." (Photo by A.R. Berger)

porphyry copper operations have sprung from primitive surface extraction of oxides that have been worked sometimes over centuries. Accordingly, the districts dotted with minor operations in the Third World offer a sound take-off point for mining entrepreneurs (Fig. 8), discouraged by the high cost of seeking new mines in lands where every geological province has been examined exhaustively over many years. If information already to be found in thousands of scattered places could be pulled together into a central repository, intelligently analyzed and fed into computers with software designed for compatibility with the needs of

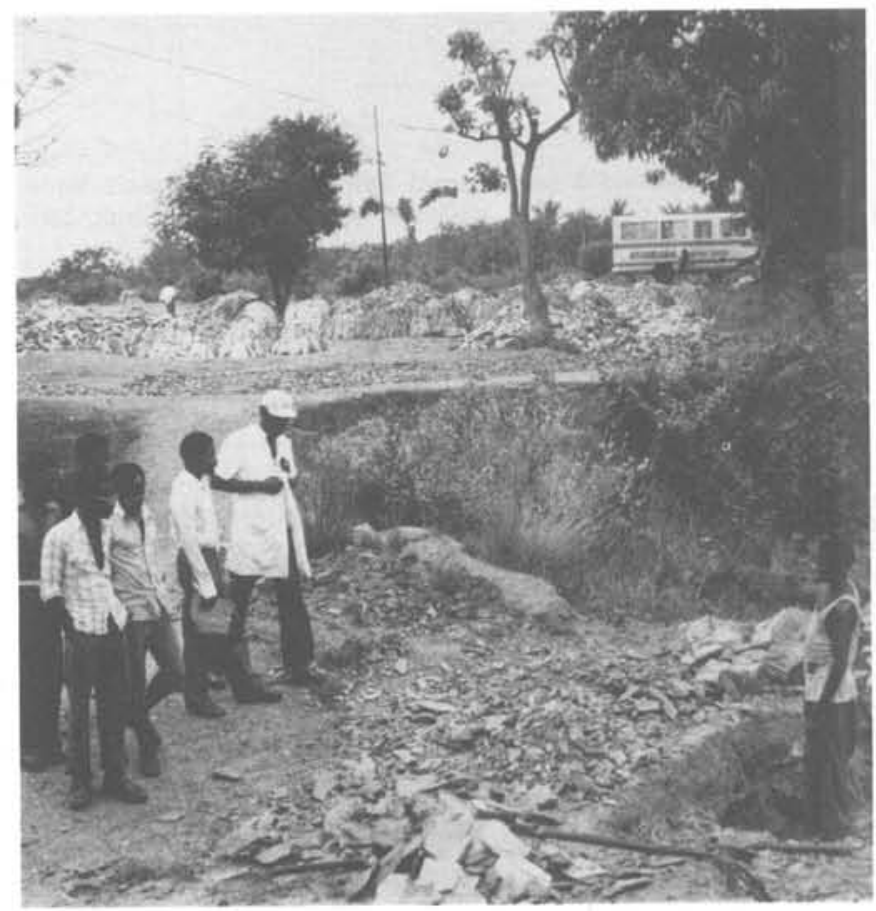

Figure 8: Entrepreneurs in stone. Quarrying flagstone for local building supplies. Achimota, Ghana. (Photo by A.R. Berger) 


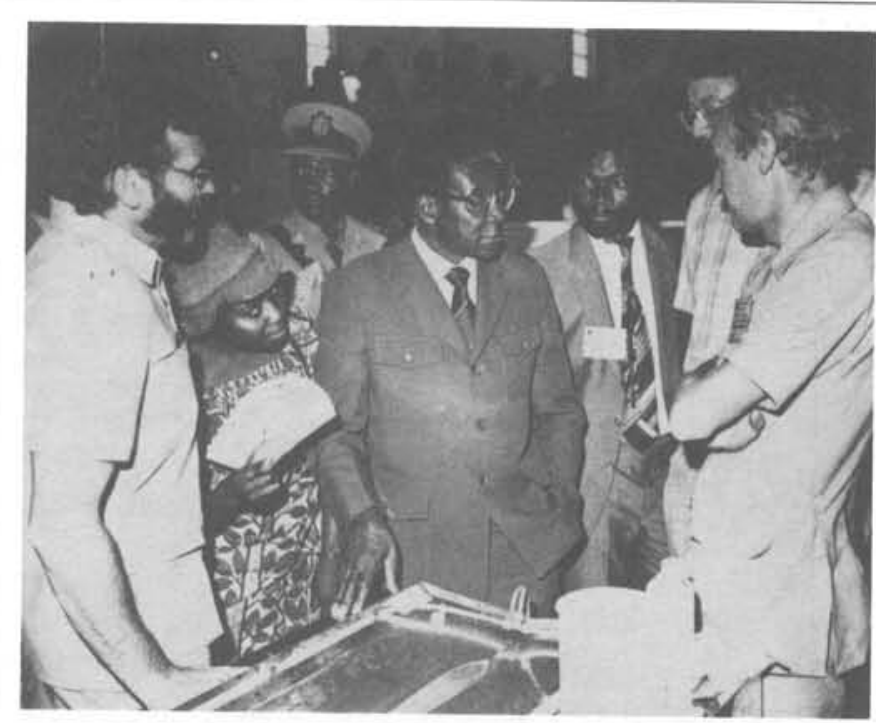

Figure 9: Robert Mugabe, President of Zimbabwe, discussing techniques for small-scale mineral processing with representatives of the U.K.-based Intermediate Technology Development Group at a technology exhibition in Bulawayo. (Photo by ITDG, which provides technical assistance for small mineral industries in developing countries)

potential investors, governments and owners of mines and/or mineral rights, a powerful vehicle would be created to provide direction for a great number of mining developments of the future (Fig. 9).

However, too many debacles of recent years have strongly indicated that even major mining houses do make gross errors in obtaining and analyzing the data required for intelligent investment decisions. Accordingly, the prime movers in seizing upon the opportunities offered by smallscale mining in the developing nations will continue to be the independent entrepreneurs, a class that has traditionally provided the main force in the development of small- and medium-sized mines. Such people when venturing abroad tend to do so somewhat blindly, dependent upon reports of dubious merit, upon local lawyers who more than occasionally work both sides of the street, and above all afflicted by ignorance of the political, economic and social culture of the country concerned.

A vital role can and should be played by an information centre with a data base that is constantly expanding, even exponentially in the early years. This would provide objective technical reporting, maintain a watching brief on the evolution of issues affecting mining, (such as the acceptance of international arbitration with industrial disputes), build up a worldwide cadre of experienced specialists, and in a comparatively short time become the first port of call for those voyaging into uncharted waters. It is, therefore, more than encouraging that the newly formed Small Mining International (see News Report elsewhere in this issue) will focus first on small mining information.

Dr. J.S. Carman is an independent mining consultant based now in Canada (61 St. Clair Avenue W., Apt. 1003, Toronto, Ontario M4V 2Y8). A graduate of Michigan Tech in mining engineering and Colombia University in mineral economics, he worked for the UN mineral exploration program from 1958 to 1976. Since then he has undertaken many projects for the World Bank, the Inter-American Development Bank and United Nations.

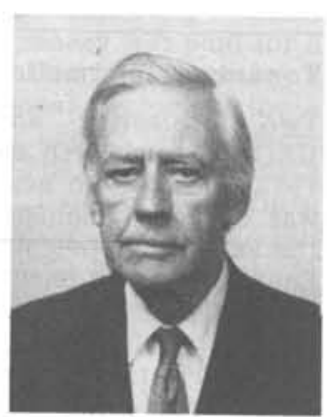

\section{References}

Anon, 1983. Second International Symposium on Small Mine Economies and Expansion. Miller Freeman Publications, San Franciseo, Calif., 200p.

Brooks, D.B., 1973. Minerals: An expanding or a dwindling resource? Department of Energy, Mines and Resources (Canada), Mineral Bulletin MR 134, Ottawa, 17p.

Carman, J.S,. (eds.), 1979. Obstacles to Mineral Development: A Pragmatic View. Pergamon, 160p.

Carman, J.S., 1985. The contribution of small-scale mining to world mineral production. Natural Resources Forum, v. 9, no. 2 , p. $119-124$.

Dahlberg, E.H., 1984. Small-Scale Gold Mining: A Manual Based on Experience in Suriname. Intermediate Technology Publications, London, 51 p.

Larson, E.D., Ross, M.H. and Williams, R.H., 1986. Beyond the era of materials. Scientific American, v. 254 , no. 6 , p. 34-41.

Meyer, R.F. and Carman, J.S. (eds.), 1980. Proceedings of the First International Conference on the Future of SmallScale Mining. MeGraw Hill/UNITAR, New York, 501p.

Neilson, J.M. (ed.), 1982. Strategies for Small-Scale Mining and Mineral Industries; Report of a Regional Workshop. Association of Geoscientists for International Development Report III, v. 8, Bangkok, Thailand, 210p.
UN, 1972. Small-Seale Mining in the Developing Countries. United Nations Department of Economic and Social Affairs. ST/ECA/155, 17lp.

Yuill, W.G., 1985. The importance of being small. Transactions of the Institute of Mining and Metallurgy, Section B (Applied Earth Sciences), v. 94, p. B107-B114. 